\title{
Strategi meningkatkan motivasi belajar mahasiswa dengan model Learning Cycle pada Mata Kuliah Sejarah Sastra Indonesia
}

\author{
Titian Berkat Gea ${ }^{\mathrm{a}, 1}$, R. Kunjana Rahardi ${ }^{\mathrm{b}, 2^{*}}$, Yuliana Setyaningsih ${ }^{\mathrm{c}, 3}$, Pranowo ${ }^{\mathrm{d}, 4}$ \\ a b,b,d, Magister Pendidikan Bahasa Indonesia, FKIP, Universitas Sanata Dharma Yogyakarta \\ ItitiangeaI991@gmail.com; rahardi.kunjana@gmail.com; yuliapbsi@gmail.com; prof.pranowo2@gmail.com \\ * korespondensi penulis
}

\begin{tabular}{lll}
\hline Informasi artikel & ABSTRAK \\
\hline $\begin{array}{l}\text { Sejarah artikel: } \\
\text { Diterima }\end{array}$ & : 20 Juni 2020 & Penelitian ini bertujuan untuk mendeskripsikan strategi meningkatkan motivasi \\
Revisi & : Oktober 2020 & belajar mahasiswa dengan model learning cycle pada mata kuliah sejarah sastra \\
Dipublikasikan $\quad$ : Oktober 2020 & Indonesia. Penelitian dilaksanakan dengan menggunakan metode kualitatif \\
\hline Kata kunci: & deskriptif. Tenik pengumpulan data menggunakan observasi dan wawancara dan \\
Learning cycle & analisis data dilakukan dengan cara reduksi data, penyajian data dan penarikan \\
Motivasi belajar & kesimpulan. Subjek penelitian adalah mahasiswa pendidikan bahasa dan sastra \\
Sejarah Sastra Indonesia & Indonesia angkatan tahun 2019 di Universitas Sanata Dharma. Berdasarkan hasil \\
& penelitian menunjukkan adanya peningkatan motivasi belajar mahasiswa dalam \\
& mata kuliah sejarah sastra Indonesia dengan model learning cycle 5E. Hal tersebut \\
& dilihat dari peningkatan persentase motivasi belajar yaitu pertemuan pertama \\
& sebesar 68,63\%, pertemuan kedua meningkat menjadi 75,50\% dan pada \\
& pertemuan ketiga sebesar 76,25\%.
\end{tabular}

Key word:

Learning cycle

Motivation of learning

History of Indonesian Literature

\section{ABSTRACT}

This study aims to describe a strategy to increase student learning motivation using the learning cycle model in the Indonesian literature history course. The research was conducted using descriptive qualitative methods. Data collection techniques used observation and interviews and data analysis was carried out by means of data reduction, data presentation and drawing conclusions. The research subjects were students of 2019 Indonesian language and literature education at Sanata Dharma University. Based on the results of the study showed an increase in student motivation in the course of Indonesian literature history using the 5E learning cycle model. This can be seen from the increase in the percentage of learning motivation, namely the first meeting was $68.63 \%$, the second meeting increased to $75.50 \%$ and the third meeting was $76.25 \%$.

\section{Copyright (C) 2018 Universitas Ahmad Dahlan. All Right Reserved}

\section{Pendahuluan}

Sejarah sastra Indonesia adalah salah satu mata kuliah wajib yang dimuat dalam kurikulum jurusan Pendidikan Bahasa dan Sastra Indonesia (PBSI) di Universitas Sanata Dharma. Mata kuliah Sejarah sastra Indonesia umumnya mempelajari tentang perkembangan kesusastraan Indonesia dimulai dari tahun I900an (angkatan Balai Pustaka) hingga tahun 2000-an (sastra Indonesia mutakhir). Menurut Yudiono (2010:26) "Sejarah sastra merupakan cabang ilmu sastra yang mempelajari perumbuhan dan perkembangan sastra suatu bangsa”. Maka, dalam pembelajaran sejarah Sastra Indonesia terdapat dua topik besar yang wajib dikuasai oleh mahasiswa jurusan Bahasa dan Sastra Indonesia yaitu: I) perkembangan kesusastraan serta peritiwa-peristiwa yang terkait di dalamnya . 2) membahas karya-karya penting yang ikonik di setiap periodenya. (Hayati, 20I0:56). Melalui mata kuliah sejarah sastra Indonesia mahasiswa juga diharapkan mampu mengenal lebih jauh tentang para tokoh sastrawan, memahami fungsi dan manfaat sastra dalam masyarakat, serta bagaimana sastra kini menjadi salah satu ilmu pengetahuan.

Membahas tentang sejarah bagi sebagian orang dianggap sebagai pembahasan yang menjenuhkan. Sejarah dipandang sebagai pembelajaran yang berfokus pada kemampuan menghafal deretan tahuntahun peristiwa yang terjadi di masa lampau (Ermayanti, 2017:3). Persepsi keliru ini menjadikan pembelajaran sejarah menjadi kurang disenangi dan 
diminati oleh para siswa/mahasiswa. Sementara pembelajaran sejarah sangat penting dalam kehidupan seseorang, seperti ungkapan John Seeley "history make man be wise" yang bermakna bahwa mempelajari dan memahami sejarah akan mengarahkan seseorang bepikir lebih bijak.

Demikian halnya juga dalam pembelajaran sejarah sastra Indonesia, mahasiswa bukan hanya dituntut untuk mengetahui perkembangan sastra di Indonesia namun menjiwai setiap perjalanan karya yang ditulis oleh para sastrawan di masanya dan mampu meningkatkan daya apresiasi dan berpikir kristis yang tinggi terhadap karya-karya di masa lampau.

Namun pada kenyataannya, banyak mahasiswa jurusan PBSI di Universitas Sanata Dharma yang kurang memiliki motivasi untuk menggali informasi dalam mata kuliah wajib ini. Asumsi dasar tentang sejarah sastra Indonesia sebagian besar mempengaruhi tindakan mereka dalam merespon pembelajaran, sehingga kondisi ini mengharuskan pengajar sejarah sastra memilih dan menerapkan model pembelajaran yang tepat.

Hayati (2010:56) dalam artikelnya menyatakan bahwa pada umumnya pengajaran sejarah sastra Indonesia yang digunakan oleh dosen masih menggunakan sistem pengajaran konvesional dengan berfokus pada metode ceramah dan hafalan. Tentu ini mengakibatkan terciptanya lingkungan kelas yang kurang menarik, membosankan, kaku dan monoton.

Model pengajaran konvensional diterapkan dalam pembelajaran sejarah sastra Indonesia malah semakin mengaburkan minat mahasiswa dalam memahami materi dalam mata kuliah ini. Mata kuliah sejarah sastra Indonesia sepertinya masih belum menjadi mata kuliah favorit bagi sebagian besar mahasiswa jurusan PBSI. Bahkan sekalipun metode yang digunakan oleh para dosen cukup bervariasi, mulai dari metode ceramah hingga pada metode diskusi. Tidak sedikit mahasiswa bertindak pasif dalam kegiatan diskusi kelompoknya. Ketidakmerataan motivasi dan minat belajar sejarah sastra Indonesia di kelas menghasilkan pembelajaran yang tidak efekteif dan terkesan monoton. Mengapa tidak, jika dalam proses penyampaian pendapat dan gagasan hanya dilakukan oleh beberapa mahasiswa.

Sementara yang diharapkan adalah mata kuliah sejarah sastra Indonesia dapat diterima oleh mahasiswa sebagai sesuatu yang rasional dan kognitif serta dapat mengarahkan mahasiswa dalam mengembangankan pengetahuannya tentang sejarah sastra Indonesia. Belajar sejarah sastra Indonesia tidak sesederhana mengingat pembabakan atau periodisasi sastra di Indonesia namun dalam mata kuliah ini mengarahkan mahasiswa pada pemahaman mendalam terhadap karya-karya sastra dari genre yang beragam dan hal tersebut tidak dapat tercapai jika motivasi dalam diri mahasiswa itu sendiri tidak ada.

Motivasi dalam kegiatan pembelajaran sangatlah penting. Motivasi menjadi penggerak utama yang muncul dalam diri seseorang secara alami dan menimbulkan minat yang tinggi dalam mengikuti kegiatan belajar. Dengan adanya motivasi memudahkan seseorang dalam mencapai kualitas belajar yang maksimal. Menurut Astuti (2010:67) motivasi belajar merupakan sesuatu yang menjadi pendorong dan penggerak siswa untuk belajar. Siswa dengan motivasi belajar yang baik akan terlihat dari tindakannya dalam menanggapi setiap pelajaran. Siswa akan lebih fokus dan terarah dalam mempelajari sesuatu hal yang baru, bukan hanya mempelajari namun memahami dan mendalaminya. Dengan kata lain, motivasi merupakan fondasi seseorang dalam mencapai pengalaman belajar yang berkualitas dan maksimal. Berhasil tidaknya sebuah pembelajaran tergantung pada lingkungan belajarnya. Lingkungan belajar yang baik adalah suasana belajar yang mampu menumbuhkan motivasi dalam diri pelajarnya. Oleh karena itu, seorang pengajar sebelum merancang pembelajaran maka harus terlebih dahulu memahami kebutuhan, motif atau minat para siswanya. Melalui pengamatan tersebut menjadi dasar bagi pengajar dalam menentukan pola pembelajaran yang tepat. Adanya motivasi dalam kegiatan belajar mengajar tidak hanya menjadi komponen penting yang harus dihadirkan dalam mncapai keberhasilan pengajaran namun juga menjadi salah satu faktor kefektifan pembelajaran tersebut. Dalam meningkatkan motivasi belajar, terdapat beberapa aspek yang perlu diperhatikan yaitu atensi (attention), relevansi, kepercayaan diri dan kepuasaan siswa dalam belajar. Motivasi dapat diklasifikasikan menjadi dua jenis yaitu motivasi instrinsik dan motivasi ekstrinsik (Hapsari, 2005:74). Motivasi instrinsik diartikan sebagai motivasi belajar yang murni muncul dari dalam diri seseorang tanpa dipengaruhi orang lain atau lingkungan. Sedangkan motivasi ekstrinsik merupakan sebuah dorongan belajar yang muncul bukan secara alami berasal dari dalam diri seseorang namun dipengaruhi oleh pihak yang ada di luar dirinya, baik dari orang lain maupun lingkungan sekitarnya.

Selanjutnya, Sardiman (201I: 83) menyatakan bahwa, "ciri-ciri motivasi yang ada pada siswa yaitu, tekun menghadapi tugas, ulet menghadapi kesulitan, menunjukkan minat terhadap bermacam-macam masalah, lebih senang bekerja mandiri, cepat bosan pada tugas yang rutin, dapat mempertahankan pendapatnya, tidak mudah melepaskan hal yang diyakini dan senang mencari dan memecahkan 
masalah.” Sardiman menegaskan jika mahasiswa memiliki ciri-ciri tersebut menunjukkan tingkat motivasi belajar yang tinggi.

Mengajar sejarah sastra Indonesia memang menjadi tantangan tersendiri bagi pengajar untuk memikirkan strategi yang tepat. Strategi dalam konteks pembelajaran diartikan sebagai upaya dalam mendesain kegiatan pembelajaran untuk mencapai tujuan pembelajaran. Frelberg \& Driscoll (dalam Syahputra, 20I4 : I29) juga menyatakan bahwa strategi pembelajaran digunakan untuk kepentingan ketercapaian tujuan pembelajaran dari materi ajar tertentu yang diterapkan pada tingkatan pendidikan, peserta didik dan konsteks yang berbeda-beda.

Selanjutnya, Gerlach \& Ely (dalam Rusman, 2014: 159) menjelaskan bahwa strategi pembelajaran merupakan teknik yang telah dirancang dan dipilih untuk diterapkan dalam aktivitas pembelajaran untuk menciptakan pengalaman belajar yang menarik dan mengesankan kepada siswa. Dick \& Carey (dalam Aji, 2016:120) juga menegaskan jika strategi pembelajaran bukan hanya berkaitan dengan rangkaian aktivitas dalam kelas, tetapi juga keseluruhan komponen pembelajarannya yang semuanya itu mengarah pada proses pembimbingan siswa dalam memperoleh kompetensi diharapkan. Berdasarkan beberapa definisi yang diuraikan maka strategi belajar dapat disimpulkan sebagai upaya yang dilakukan dalam menciptakan aktivitas pembelajaran yang dinamis, kreatif dan menyenangkan demi mencapai pembelajaran yang efektif dan bermanfaat bagi siswa.

Maka, salah satu strategi belajar yang harus dipikirkan seorang pengajar dalam meningkatkan motivasi belajar siswa adalah model pembelajaran yang digunakan. Namun hal tersebut sering kali terlewatkan atau terabaikan oleh pengajar. Mahasiswa dianggap sudah dewasa untuk memilih cara sendiri untuk memotivasi mereka dalam belajar. Padahal, pada kenyataannya motivasi belajar sesungguhnya harus dibangun lewat pemilihan strategi dan model pembelajaran yang dilakukan dosen di dalam kelas.

Demikian halnya yang terjadi dalam pembelajaran mata kuliah sejarah sastra Indonesia di jurusan PBSI, Universitas Sanata Dharma. Maka, model learning cycle atau model belajar bersiklus dapat menjadi salah satu pilihan model pembelajaran yang dapat diterapkan oleh dosen dalam pembelajaran sejarah Sastra Indonesia. Model pembelajaran ini dikembangkan berdasarkan teori konstruktivisme.

Konstruktivisme menurut Sardiman (2008) adalah "salah satu filsafat pengetahuan yang menekankan bahwa pengetahuan kita merupakan hasil dari konstruksi (bentukan) kita sendiri." Von Glasersfel (dalam Sardiman, 2008:37) menegaskan bahwa pengetahuan merupakan hasil dari suatu konstruksi yang diperoleh seseorang melalui kegiatan dan pengalaman yang ditemuinya. Salah satu model pembelajaran dengan pendekatan konstruktivisme adalah model learning cycle yang dikembangkan oleh Peaget.

Model pembelajaran learning cycle awalnya terdiri atas tiga fase yaitu exploration, concept development dan expansion yang diturunkan dari model fungsi mental Peaget, 3E kemudian diperluas menjadi lima fase (5E) yaitu: engage, explore, explain, elaborate, evaluate (Marek, 2008:66).

Bybee (1997) dalam Duran \& Duran (2004:5I) menyatakan bahwa dalam pendekatan model learning cycle, "siswa mendefinisikan kembali, mengatur ulang, menguraikan, dan mengubah konsep awal mereka melalui refleksi diri dan interaksi dengan teman sebaya dan lingkungannya. Peserta didik menafsirkan objek dan fenomena, dan menginternalisasi interpretasi tersebut dalam konsep pemahaman berpikir mereka."

Berdasarkan prinsip tersebut, model pembelajaran bersiklus memiliki cara belajar yang berpusat pada siswa. Masing-masing siswa diwajibkan memahami materi pembelajaran yang telah disiapkan guru secara mandiri. Pertanggungjawaban atas materi yang sedang dipelajari sangat dituntut dalam model pembelajaran bersiklus maka setiap individu wajib memperoleh rumusan atas materi tersebut sebagai hasil belajarnya. Selanjutnya, hasil belajar masing-masing anggota kelompok dibahas dan didiskusikan bersama dengan anggota lainnya. Dalam proses pengambilan kesimpulan atas materi yang dipelajari melibatkan semua anggota kelompok.

Berdasarkan latar belakang di atas, rumusan masalah dalam penelitian ini yaitu bagaimana strategi meningkatkan motivasi belajar mahasiswa dengan model learning cycle pada mata kuliah sejarah sastra Indonesia? Penelitian ini bertujuan untuk mendeskripsikan strategi pembelajaran dengan model learning cycle dalam meningkatkan motivasi belajar mahasiswa pada mata kuliah sejarah sastra Indonesia.

\section{Metode}

Metode penelitian yang digunakan adalah metode kualitatf deskriptif. Moleong (2005:6) menjelaskan bahwa penelitian kualitatif adalah penelitian dengan tujuan untuk mengetahui dan mendalami suatu fenomena secara holistik yang dialami oleh subjek penelitian. Penelitian kualitatif dilakukan di lingkungan alamiah (natural setting) di mana para partisipan mengalami masalah (Creswell, 2010:261). Lalu hasil penelitian tersebut disajikan 
secara deskriptif yaitu menguraikan data dalam bentuk kata-kata.

Damin (2002: 4I) menjelaskan bahwa penelitian deskriptif merupakan metode penelitian untuk menggambarkan kondisi konkret secara sistematis dan akurat. Penelitian deskriptif dilakukan sebagai upaya untuk menyajikan potret peristiwa atau kondisi yang terjadi baik dalam bentuk individual, situasi, atau kelompok .

Penelitian dengan pendekatan kualitatif dimaksudkan untuk mendeskripsikan strategi dalam meningkatkan motivasi belajar mahasiswa pada mata kuliah sejarah sastra Indonesia dengan menggunakan model learning cycle. Dalam memudahkan pemerolehan data maka peneliti menggunakan teknik pengumpulan data berupa observasi dan wawancara. Jenis observasi yang digunakan adalah observasi partisipatif yaitu peneliti secara terbuka menunjukkan perannya sebagai observer saat berada di lapangan. Sedangkan wawancara menggunakan wawancara bersifat terbuka untuk mendapatkan pandangan dan opini dari para partisipan dalam hal ini mahasiswa dan dosen.

Penelitian dilaksanakan di jurusan Pendidikan Bahasa dan sastra Indonesia, Universitas Sanata Dharma, Yogyakarya. Mahasiswa jurusan PBSI yang diobservasi berjumlah 36 orang, angkatan tahun 2019. Peneliti melakukan pengumpulan data dengan menggunakan lembar pedoman observasi dalam mengamati peningkatan motivasi belajar mahasiswa. Sedangkan, wawancara dilakukan secara tidak terstruktur yaitu metode pengumpulan data melalui tanya jawab atau wawancara secara terbuka dan tanpa panduan pertanyaan dari peneliti (Sugiyono, 2008 :194). Wawancara dilakukan untuk mendapatkan beberapa informasi dari dosen pengajar mata kuliah sejarah sastra Indonesia, berkaitan dengan data yang tidak ditemukan dari observasi.

Analisis data dilakukan dengan berpedoman pada prosedur analisis menurut Moleong (2005:16I) yang terdiri atas: reduksi data, penyajian data dan penarikan kesimpulan. Pertama, reduksi data dilakukan dengan memilih data yang muncul melalui proses validasi di lapangan yang disesuaikan dengan tujuan penelitian. Kedua, penyajian data yaitu data yang telah dikelompokkan secara sistematis dan disajikan dalam bentuk uraian naratif dan bagan untuk mempermudah peneliti dalam memahami permasalah yang terjadi. Terakhir, penarikan kesimpulan yaitu membuat kesimpulan dari pemerolehan data yang didapatkan terkait tentang strategi meningkatkan motivasi belajar mahasiswa dengan model learning cycle pada mata kuliah sejarah sastra Indonesia.

\section{Hasil dan Pembahasan}

Penerapan model pembelajaran learning cycle pada mata kuliah sejarah sastra Indonesia bertujuan untuk mengatasi persoalan rendahnya motivasi belajar mahasiswa terhadap mata kuliah tersebut. Tantangan pembelajaran sejarah sastra yang paling utama adalah pemilihan strategi belajar yang tepat. Apabila pengajar salah atau kurang bijak dalam menentukan strategi belajar maka akan berdampak pada kurangnya minat dan motivasi mahasiswa. Maka, permasalahan inilah yang dicermati oleh pendidik sastra yang kemudian dicari solusinya.

Penerapan model pembelajaran learning cycle ini dilakukan oleh dosen di dalam kelas dengan materi kuliah kesusastraan tahun I930an. Pengajar menerapkan learning cycle 5 fase yaitu engage, explore, explain, elaborate, evaluate. Dalam penerapan learning cycle $5 \mathrm{E}$ ini, observer mengamati tindakan dan perkembangan aktivitas mahasiswa yang merujuk pada ada/tidaknya peningkatan motivasi belajar mahasiswa.

Adapun langkah-langkah strategi yang diterapkan untuk meningkatkan motivasi belajar mahasiswa pada mata kuliah sejarah sastra Indonesia dengan model pembelajaran learning cycle $5 E$ :

\section{Engage (Mengajak)}

Dosen menumbuhkan minat dan keingintahuan mahasiswa dengan memberikan kesempatan kepada mereka untuk mencari tahu tentang materi kesusastraan 30an (Pujangga Baru) yang akan segera dibahas, seperti: perbedaan angkatan balai pustaka dan pujangga baru, hal-hal penting yang terjadi dalam tahun 1930an, corak sastra tahun I930an, dll. Topik tersebut akan mengarahkan mahasiswa untuk melakukan pencarian informasi secara mandiri dan menumbuhkan rasa keingintahuan yang tinggi terhadap hal yang tidak diketahui sebelumnya

2. Explore (Menyelidiki)

Dosen memberikan kesempatan kepada mahasiswa untuk membentuk kelompok secara mandiri. Dalam hal ini dosen berperan sebagai fasilitator. Mahasiswa dibagi dalam I5 kelompok dengan beranggotakan tiga orang setiap kelompok. Kemudian, masing-masing mahasiswa mencari informasi dan data-data terkait corak sastra tahun 1930an serta sastrawan-sasatrawan terkenal pada masa itu. Kemudian bersama kelompoknya membuat daftar informasi yang disertai bukti atau sumber yang akurat untuk validasi. Tidak hanya sampai di situ, setiap kelompok mencoba melakukan alternatif pemecahan masalah dengan memunculkan pertanyaan-pertanyaan baru yang berkaitan dengan topik yag dibahas lalu dijawab berdasarkan data yang diperoleh, melakukan pembacaan atau pengamatan kembali sumber- 
sumber yang diperoleh lalu kemudian membuat suatu kesimpulan.

\section{Explain (menjelaskan)}

Dosen memberikan ruang kepada mahasiswa untuk menyampaikan gagasan dan pemahamannya secara terbuka namun tetap meminta pertanggunjawaban berupa bukti dan klarifikasi. Dosen juga memberikan pertanyaan selingan terkait materi yang akan dibahas untuk mengarahkan dan membentuk konsep berpikir mahasiswa terhadap topik. Sebagai fasilitator, dosen tetap mendengar secara kritis penjelasan antar mahasiswa dan memandu diskusi.

Dalam fase ini mahasiswa diminta untuk menjelaskan konsep-konsep yang ditemukannya dengan menggunakan semua data yang telah dikumpulkan sebelumnya untuk memperkuat gagasan yang diajukan.

Setelah itu, dosen memberi penjelasan secara teoretis tentang konsep yang dibahas dengan mengaitkan penjelasan mahasiswa sebagai gambaran umum untuk pemahaman topik berikutnya

4. Elaboration (memperluas)

Dosen mengigatkan mahasiswa untuk mempertimbangkan data setiap kali mereka mengeksplorasi topik atau persoalan baru, menggunakan sumber-sumber referensi terpercaya dan menetapkan pemahaman dengan menghubungkannya dengan data yang didapatkan sehingga ditemukannya sebuah konsep dan informasi yang valid. Dosen tetap memfasilitasi mahasiswa untuk menerapkan konsep baru yang ditemukannya sebagai pendekatan praktis agar mahasiswa mudah melakukan pengamatan, memecahkan persoalan, dan memberi keputusan.

5. Evaluation (menilai)

Selama proses pembelajaran berlangsung dosen melakukan observasi terhadap perubahan atau peningkatan konsep berpikir mahasiswanya serta mencari bukti bahwa mahasiswa tersebut telah mengalami perubahan (Duran \& Duran. 2004:53). Melalui kegiatan evaluasi, mahasiswa dapat melakukan evaluasi diri (self assessment), memahami kekurangan dan kelebihannya selama proses pembelajaran atau penilain antar teman sebaya (peer-asessment) untuk saling memberi komentar tentang temannya.

Dalam tahap ini, mahasiswa juga diharapkan dapat menilai dirinya sendiri atau temannya serta hasil belajarnya secara objektif dan mampu menyadari potensi-potensi yang ada dalam dirinya

Berdasarkan penjelasan naratif dari penerapan model learning cycle 5E mendeskripsikan bahwa penerapan model tersebut dalam pembelajaran sejarah sastra Indonesia lebih banyak melibatkan mahasiswa dalam proses pembelajaran dan pencarian sumber informasi. Kondisi ini memperlihatkan adanya perubahan sikap dan respon mahasiswa terhadap pembelajaran sejarah sastra Indonesia. Perubahan sikap dan peningkatan motivasi belajar mahasiswa dalam mata kuliah sejarah sastra dapat dilihat dari tabel I berikut ini.

\section{Tabel I. Persentase Data Hasil Observasi Terhadap Motivasi Belajar Mahasiswa Menggunakan Model Learning Cycle}

\begin{tabular}{|c|c|c|c|c|}
\hline \multirow[t]{2}{*}{ Indikator } & \multicolumn{3}{|c|}{$\begin{array}{l}\text { Persentase tiap indikator dalam } \\
\text { pertemuan ke }\end{array}$} & \multirow[t]{2}{*}{$\begin{array}{c}\text { Rata- } \\
\text { rata } \\
(\%)\end{array}$} \\
\hline & I & II & III & \\
\hline I & 70 & 85 & 85 & 80.00 \\
\hline 2 & 75 & 78 & 80 & 77.67 \\
\hline 3 & 60 & 68 & 69 & 65.67 \\
\hline 4 & 70 & 75 & 75 & 73.33 \\
\hline 5 & 60 & 62 & 62 & 61.33 \\
\hline 6 & 76 & 77 & 77 & 76.67 \\
\hline 7 & 78 & $8 \mathrm{I}$ & 82 & 80.33 \\
\hline 8 & 60 & 78 & 80 & 72.67 \\
\hline Rata-rata & 68.63 & 75.50 & 76.25 & \\
\hline
\end{tabular}

Hasil menunjukkan bahwa adanya peningkatan dalam indikator motivasi belajar mahasiswa pada mata kuliah sejarah sastra Indonesia dengan penerapan model learning cycle $5 E$ dalam tiga kali pertemuan yang dilakukan oleh peneliti.

Tabel 2. Persentase Rata-rata Indikator Motivasi Belajar Mahasiswa dengan Model Learning Cycle Indikator Motivasi Belajar Rata- Kriteria

(\%)

\begin{tabular}{ccc} 
Tekun menghadapi tugas & 80.00 & Tinggi \\
\hline Ulet menghadapi kesulitan & 77.67 & Tinggi
\end{tabular}

Menunjukkan minat terhadap beragam $\quad 65.67 \quad$ Tinggi masalah

\begin{tabular}{ccc}
\hline Lebih senang bekerja mandiri. & 73.33 & Tinggi \\
\hline Cepat bosan pada tugas yang rutin & 61.33 & Tinggi \\
\hline Dapat mempertahankan pendapatnya & 76.67 & Tinggi \\
\hline Dapat mempertahankan pendapatnya & 80.33 & $\begin{array}{r}\text { Sangat } \\
\text { Tinggi }\end{array}$ \\
\hline Senang mencari dan memecahkan masalah & 72.67 & Tinggi \\
\hline
\end{tabular}

Tabel 3 Pedoman konversi persentase skor lembar observasi

\begin{tabular}{cc}
\hline Interval Persentase $(\%)$ & Kriteria \\
\hline $80<\mathrm{P} \leq \mathrm{I00}$ & Sangat tinggi \\
\hline $60<\mathrm{P} \leq 80$ & Tinggi \\
\hline $40<\mathrm{P} \leq 60$ & Sedang \\
\hline $20<\mathrm{P} \leq 40$ & Rendah \\
\hline $0<\mathrm{P} \leq 20$ & Sangat Rendah \\
\hline \multicolumn{2}{c}{$($ Widyoko, 2009:242) }
\end{tabular}

Berdasarkan rata-rata persentase data hasil observasi setiap indikator menunjukkan terjadinya peningkatan motivasi belajar mahasiswa dengan 
kriteria tinggi dalam kelas mata kuliah sejarah sastra Indonesia dengan menggunakan model pembelajaran Learning cycle 5E.

\section{Persantunan}

Penulis mengucapkan terima kasih kepada seluruh pihak yang telah berperan dalam membantu penelitian ini. Selanjutnya kepada tim editor Bahastra yang telah membantu publikasi artikel ilmiah ini.

\section{Simpulan}

Berdasarkan hasil penelitian yang diperoleh maka dapat disimpulkan bahwa:

I. Model learning cycle 5E dapat diterapkan dalam pembelajaran sejarah sastra Indonesia di jurusan Pendidikan Bahasa dan Sastra Indonesia, Universitas Sanata Dharma.

2. Penerapan model learning cycle menghasilkan proses belajar dinamis dan aktif yang berpusat pada mahasiswa.

3. Ada peningkatan motivasi belajar mahasiswa dalam mata kuliah sejarah sastra Indonesia dengan menggunakan model learning cycle 5E. Terdapat peningkatan persentase hasil observasi yang dilakukan selama tiga kali pertemuan yaitu persentase pertemuan pertama sebesar 68,63\%, pertemuan kedua meningkat menjadi $75,50 \%$ dan pertemuan ketiga sebesar 76,25\%.

\section{Daftar Pustaka}

Aji, Wisnu Nugroho. (2016). Model Pembelajaran Dick and Carey dalam Pembelajaran Bahasa dan Sastra Indonesia.Kajian Linguistik dan Sastra, Vol.I No.2, tahun 2016, hlm.II9-I26.

Creswell, J.W. (2010). Research Design: Pendekatan Kualitatif, Kuantitatif dan Mixed. Yogyakarta: Pustaka Pelajar.

Damin,Sudarwan. (2002). Menjadi Peneliti Kualitatif. Bandung: Pustaka Setia.

Duran, Lena Ballone and Emilio Duran. (2004). The 5E Instructional Model: A Learning Cycle Approach fo Inquiry-Based Science Teaching. The Science Education Review, 3(2), 2004, pp.49-58.

Ermayanti, Ade. (2017). Persepsi Peserta Terhadap Pembelajaran Sejarah di SMA Negeri I Gondang Nganjuk. Simki-Pedagogia Vol. OI No. 03 Tahun 2017.

Hapsari, Sri. (2005). Bimbingan dan Konseling SMA Untuk Kelas XII. Jakarta : PT Grasindo.

Hayati, Yeni. (20I0). Inovasi Perkuliahan Sejarah Sastra Indonesia dengan Menggunakan Metode
Diskusi Kelompok Model Kepala Bernomor. Komposisi. Vol. II, No. I, tahun 2010, hlm. 56-6I.

Marek, Edmund A. (2008). Why The Learning Cycle. Journal of Elementary Science Education, Vol. 20, No. 3 (Summer 2008), pp. 63-69.

Moleong, Lexy J. (2005). Metodologi Penelitian Kualitatif. Bandung: Remaja Rosdakarya.

Rusman. (2013). Model-model Pembelajaran Mengembangankan Profesional Guru. Jakarta: Rajawali Pers.

Sardiman, AM. (2008). Interaksi dan Motivasi Belajar Mengajar. Jakarta : Raja Grafindo Persada.

Sugiyono, (2008). Metode Penelitian Kuantitatif Kualitatif dan R\&D. Bandung: Alfabeta.

Syahputra, Idham. (20I4). Strategi Pembelajaran Bahasa Inggris sebagai bahasa Asing dalam Meningkatkan Kemampuan Berbahasa Siswa. Kutubkhanah: Jurnal Penelitian sosial keagamaan, Vol.17, No.I Januari-Juni 2014, hlm. I27-I 45.

Widoyoko, Eko Putro. (2009). Evaluasi Program Pembelajaran.Yogyakarta; Pustaka Belajar.

Yudiono K.S. (2010). Pengantar Sejarah Sastra Indonesia. Jakarta: Grasindo. 